\title{
ДО ПИТАНЬ ПРОЦЕСУАЛЬНОГО ПОРЯДКУ ЗВІЛЬНЕННЯ ВІД КРИМІНАЛЬНОЇ ВІДПОВІДАЛЬНОСТІ У ЗВ' ЯЗКУ ЗІ ЗМІНОЮ ОБСТАНОВКИ
}

Глобенко Г. І.

\begin{abstract}
у статmі проведено ретроспективний аналіз положень законодавчих актів, на підставі яких розглядаються питання щодо становлення та розвитку як вітчизняного інституту звільнення від кримінальної відповідальності у зв'язку зі зміною обстановки, так і окремих країн пострадянського простору. Крім цього, здійснюється аналіз положень чинного кримінального законодавства України, що безпосередньо стосуються питань з'ясування зміни обстановки, а саме визначення таких важливих чинників, як втрата суспільної небезпечності вчиненого діяння та втрата особою суспільної небезпечності. У рамках розгляду кримінального процесуального законодавства досліджуються як передумови, так і процесуальний порядок складання прокурором відповідного клопотання про звільнення від кримінальної відповідальності за досліджуваною підставою. Також аналізуються погляди провідних науковців з окремих питань, що стосуються теми дослідження. Щодо цих питань аргументовано викладається авторське бачення їх вирішення.

На підставі викладеного сформульовано пропозиції щодо удосконалення положень кримінального процесуального законодавства з питань, що безпосередньо стосуються фіксування в матеріалах кримінального провадження факту можливості звільнення підозрюваного від кримінальної відповідальності та надання його згоди на таке звільнення. Також акцентується увага на питаннях, що стосуються з'ясування прокурором у потерпілого думки щодо можливості звільнення підозрюваного від кримінальної відповідальності і складання про це відповідного протоколу. Автором з метою удосконалення правозастосовної діяльності надаються обгрунтовані роз'яснення та рекомендації в частині належного відображення у мотивувальній частині клопотання про звільнення від кримінальної відповідальності факту зміни обстановки.
\end{abstract}

Ключові слова: кримінальне провадження, зміна обстановки, звільнення від кримінальної відповідальності, рішення, підстави, умови.

В статье проведен ретроспективный анализ положений законодательных актов, на основании которых рассматриваются вопросы становления и развития как отечественного института освобождения от уголовной ответственности в связи с изменением обстановки, так и отдельных стран постсоветского пространства. Кроме этого, осуществляется анализ положений действующего уголовного законодательства Украины, которые непосредственно касаются вопросов выяснения изменения обстановки, а именно определения таких важных факторов, как утрата общественной опасности совершенного деяния и утрата лицом общественной опасности. В рамках рассмотрения уголовного процессуального законодательства исследуются как предпосылки, так и процессуальный порядок составления прокурором ходатайства об освобождении от уголовной ответственности по исследуемому осно-

Глобенко Г. І., 2019 ванию. Также рассматриваются взгляды ведущих ученых по отдельным вопросам, которые касаются темы исследования. По этим вопросам излагается авторское аргументированное видение их решения.

На основании изложенного сформулированы предложения, касающиеся усовершенствования уголовного процессуального законодательства, которые затрагивают фиксацию в материалах соответствующего уголовного производства возможности освобождения подозреваемого от уголовной ответственности, а также его согласие на это. Акцентируется внимание на вопросах выяснения прокурором у потерпевшего его мнения о возможности освобождения подозреваемого от уголовной ответственности и составления об этом соответствующего протокола. Автором с целью усовершенствования правоприменительной деятельности предоставляются обоснованные разъяснения и рекомендации в части надлежащего отражения в мотивировочной части ходатайства об освобождении от уголовной ответственности факта изменения обстановки.

Ключевые слова: уголовное производство, изменение обстановки, освобождение от уголовной ответственности, решение, основания, условия.

The author of the article provided a retrospective analysis of the provisions of the legislative acts of Ukraine and other post-soviet countries. On the basis of this analysis, the issues of formation and development of a national institute of criminal liability exemption due to the changing situation were considered. The author made a detailed analysis of the provisions of the current criminal legislation of Ukraine, which directly relate to the issues of clarifying the change of circumstances, namely, the identification of such important factors as the loss of socially dangerous nature of the relevant act and the loss of a person of public danger. During the analysis of the criminal procedural legislation, the author examined both the prerequisites and the procedure for the prosecutor to file a motion for release from criminal liability for the investigated grounds. The views of leading scholars on particular issues related to the topic of the study were also considered and formulated some author's statements.

On the basis of the above, proposals for improving the provisions of the criminal procedural legislation on issues directly related to fixing in the materials of the respective criminal proceedings the possibility of releasing the suspect from criminal responsibility and granting his consent for such release were formulated. It was also focused on issues relating to the prosecutor's view of the victim's opinion as to the possibility of resolving criminal proceedings in this manner and drawing up an appropriate protocol. The author, in order to improve law enforcement activities, provided some explanations and recommendations regarding the proper reflection in the motivating part of the petition for the release from criminal responsibility of the fact of changing the situation.

Key words: criminal proceedings, change of situation, release from criminal responsibility, decisions, grounds, conditions. 
Постановка проблеми та її актуальність. У законодавстві країн світової спільноти поряд із заходами державного примусу, що безпосередньо стосуються кримінальної відповідальності та покарання, також $\epsilon$ i альтернативні інструментарії. Вони стосуються випадків, за яких мета покарання щодо особи, яка вчинила злочин, може бути досягнута без реального його виконання. У контексті розгляду даного питання особливої актуальності набувають процесуальні аспекти інституту звільнення від кримінальної відповідальності у зв'язку зі зміною обстановки. Зокрема, це пов'язано 3 тим, що досліджувана підстава порівняно з іншими бере свої витоки лише з початку XX ст., а отже, практика застосування досліджуваного інституту значно менша. Погоджуючись 3 думкою В.С. Кульчицького та Б.Й. Тищика, що «хто не знає свого минулого <...> не годен пошани» $[1$, с. 7], розглянемо окремі етапи його становлення та розвитку. Так, О.О. Житний, досліджуючи питання виникнення в законодавстві вказаних норм, зазначає, що в ст. 16 Керівних начал з кримінального права (в Україні набули чинності з 1920 р.) йшлося про зникнення умов, за яких певне діяння чи особа, яка його вчинила, уявлялися небезпечними для даного ладу. На підставі таких положень у 1926 р. до КПК УРСР було введено ст. 4-1, за якою прокурор і суд отримали право не порушувати або закривати провадження в справі, якщо через змінені умови вчинене втратило всяку суспільну небезпеку [2, с. 27]. Отже, при започаткуванні досліджуваної інституції законодавець мав на увазі зникнення умов, тобто зовнішніх змін, що не залежали від волі суб'єкта. Дещо інша позиція законодавця була викладена у ст. 43 «Звільнення від кримінальної відповідальності і покарання» Основ кримінального законодавства СРСР і союзних Республік 1958 р. [3], згідно з якою передбачалося звільнення від відповідальності у зв'язку з втратою особою або вчиненим діянням суспільної небезпеки. Згодом вказані приписи трансформувались у ст. 50 КК України 1960 р. [4]. Ст. 7 КПК України 1960 р. регламентувала порядок звільнення від кримінальної відповідальності і від покарання внаслідок зміни обстановки [5]. Усі республіки, що входили до складу СРСР, також мали в своєму законодавстві таку підставу звільнення від кримінальної відповідальності. Однак після розпаду СРСР одні республіки залишили її (Україна, Білорусь, Молдова, Узбекистан, Таджикистан, Казахстан, Киргизія і ін.), а інші держави виключили ії взагалі (Литва, Латвія, Естонія та ін.) $[6$, с. 178].

Аналіз останніх досліджень і публікацій. Кримінально-правові та процесуальні аспекти звільнення від кримінальної відповідальності як взагалі, так і у зв'язку зі зміною обстановки досліджували такі науковці, як Ю.В. Баулін, С.М. Благодир, О.Г. Губська, О.О. Житний, М.В. Жогін, І.Г. Івасюк, Л.М. Карнеєва, В.Г. Лукашевич, Ю.В. Луценко, М.М. Михеєнко, Д.П. Письменний, М.А. Погорецький, О.О. Торбас, В.П. Шибіко та інші. Однак окремі процесуальні питання були досліджені фрагментарно та потребують подальшого дослідження.

Метою статті $\epsilon$ з'ясування окремих питань процесуального порядку звільнення від кримінальної відповідальності у зв'язку зі зміною обстановки.

Виклад основного матеріалу. Як свідчить практика, ризикованою з точки зору порушення законності $\epsilon$ норма, що дозволяє недобросовісним правозастосо- вувачам за надуманих підстав приймати рішення про звільнення від кримінальної відповідальності у зв'язку зі зміною обстановки. Таке рішення може бути прийняте щодо особи, яка вперше вчинила злочин невеликої або середньої тяжкості, крім корупційних злочинів, якщо буде визнано, що на час кримінального провадження внаслідок зміни обстановки вчинене нею діяння втратило суспільну небезпечність або ця особа перестала бути суспільно небезпечною (ст. 48 КК України). Таким чином, вказана норма передбачає дві умови такого звільнення: а) втрату діянням суспільно небезпечного характеру; б) втрату особою суспільної небезпечності. Проте К.В. Михайлов цілком слушно констатує, що не виключаються також ситуації, коли може відбутися одночасна втрата суспільної небезпечності і особою, яка вчинила злочин, і самим злочином [7, с. 61].

Під зміною обстановки у зв'язку з втратою суспільної небезпечності злочином, вчиненим особою, слід розуміти суттєві соціально-економічні, політичні, організаційно-господарські зміни в масштабі країни або окремого регіону, що відбулися незалежно від волі особи, яка вчинила злочин. Загальною властивістю таких змін $\epsilon$ те, що вони відбуваються незалежно від волі і бажання особи, а також в рівній мірі поширюються на всіх громадян країни, всіх жителів певного району або всіх працівників того чи іншого підприємства. Отже, втрачати суспільну небезпечність має не тільки один злочин, але і всі подібні злочинні діяння.

Зміна обстановки, що призводить до втрати суспільної небезпеки особою, проявляється у вчиненні нею дій, що усувають злочинність діяння, а також у перебуванні особи в умовах, які обмежують її волю на вчинення протиправних дій. Наскільки змінилася обстановка і особа втратила свою суспільну небезпеку, доводиться індивідуально щодо кожної конкретної особи. Вважаємо, що доведення зміни обстановки, котре свідчить про втрату суспільної небезпеки особою, необхідно розпочинати з виявлення умов життя та діяльності цієї особи. Даний факт має встановлюватися, зокрема, шляхом допитів близьких родичів, сусідів, колег.

Втім, передбачаючи дану умову, законодавець припускає, що між вчиненням злочину та завершенням розслідування або судовим розглядом проходить певний проміжок часу, протягом якого і відбувається зміна обстановки. Безумовно, даний період часу повинен охоплюватися строками давності притягнення до кримінальної відповідальності, передбаченими ст. 49 КК України.

У контексті викладеного О.А. Губська, Ю.В. Луценко небезпідставно звертають увагу на відмінність між звільненням від кримінальної відповідальності у зв' язку зі зміною обстановки від декриміналізації, тобто коли те чи інше діяння виключається законом з переліку кримінально карних. 3 огляду на це декриміналізація певного діяння не надає підстав для звільнення від кримінальної відповідальності за досліджуваною підставою [8, с. $11 ; 9$, с. 130]. У таких випадках підлягає застосуванню правило про зворотну дію в часі закону про кримінальну відповідальність, яке скасовує злочинність діяння (ч. 1 ст. 5 КК України). Суд виносить виправдувальний вирок за відсутністю в діянні особи складу злочину [10, с. 268].

Закінчення досудового розслідування шляхом направлення до суду клопотання про звільнення особи 
від кримінальної відповідальності за даною підставою стосується прав та законних інтересів як підозрюваного, так і інших учасників кримінального процесу, зокрема потерпілого. Окреслений чинник покладає на посадових осіб, які здійснюють кримінальне провадження, відповідальність, пов'язану з необхідністю вирішення цілої низки процесуально важливих питань. Так, положення § 2 глави 24 КПК України, що регламентують механізм реалізації матеріально-правової підстави для звільнення особи від кримінальної відповідальності, погоджені зі ст. 48 КК України і конкретизують процес реалізації умов, що містяться в ній. Однакове розуміння змісту перерахованих у законі умов має важливе значення як для вдосконалення досліджуваного інституту, так і для практики його застосування.

Законодавець як обов'язкову умову звільнення від кримінальної відповідальності розглядає згоду підозрюваного на таке звільнення (ч. 2 ст. 286 КПК України). Реальна можливість встановити ставлення особи до визнання своєї вини у вчиненні злочину з'являється безпосередньо ще під час допиту як підозрюваного. Вважаємо за логічне зазначити, що визнання особою вини та подальша її згода на таке звільнення $є$ взаємопов'язаними діями.

3 огляду на це до прийняття вказаного рішення підозрюваному мають роз'яснити, що дана підстава належить до нереабілітуючих, а також про передбачене законом право заперечувати проти завершення такого порядку провадження. Виконання зазначених процесуальних дій повинно відобразитись у відповідному протоколі. Крім того, окреслена процедура має закріпитись у положеннях вказаної вище норми.

Здійснивши аналіз ч. 3 ст. 286 КПК України, ми повністю підтримуємо погляди О.О. Торбаса з приводу того, що, хоча законодавець зобов'язав і прокурора, і суддю з'ясувати думку потерпілого при звільненні особи від кримінальної відповідальності, позиція потерпілого здебільшого ніяк не може вплинути на остаточне рішення суду. Тобто положення кримінального процесуального законодавства мають декларативний характер [11, с. 141]. Водночас ми вважаємо, що ч. 3 ст. 286 КПК України також має бути доповнена положеннями з приводу фіксування у відповідному протоколі вказаних дій щодо потерпілого.

Закон передбачає, що звільнення від кримінальної відповідальності за досліджуваною підставою можливе лише щодо особи, яка вперше вчинила злочин. Доречно звернути увагу на відсутність законодавчого тлумачення поняття «вчинення особою злочину вперше». У теорії права вказане питання характеризується розмаїттям поглядів таких науковців, як 0.О. Дудоров [12, с. 49], Г.П. Хімічева [13, с. 90], П.В. Хряпінський [14, с. 67], В.В. Ярош [15, с. 1246] тощо. Проте факт вчинення особою злочину вперше у даній категорії кримінальних проваджень входить до предмета доказування, а тому прийняття рішення за даною підставою буде законним і обґрунтованим лише за наявності відповідних даних, наприклад, довідки про несудимість з Департаменту інформаційно-аналітичної підтримки Міністерства внутрішніх справ України.

Згідно зі змістом закону звільнення від кримінальної відповідальності можливе лише за умови вчинення особою злочину невеликої або середньої тяжкості (ст. 48 КК України). Отже, вирішенню питання про прийняття вказаного рішення має передувати повне й об'єктивне дослідження обставин, що характеризують склад злочину, з метою правильної кваліфікації діяння. У зв'язку з цим Ю.В. Баулін доцільно зауважує, що ці обставини не завжди враховуються, внаслідок чого трапляються випадки закриття справ щодо осіб, які вчинили тяжкі злочини, а також осіб, які мають судимість, не зняту і не погашену судом у встановленому законом порядку $[16$, c. 149].

У контексті розгляду даного питання слід звернути увагу і на інші помилки, що трапляються у діяльності правозастосовних органів. Так, вивчення та узагальнення слідчої та судової практики вказує на те, що у змісті клопотань та ухвал не приділяється належної уваги обґрунтуванню прийняття рішення про звільнення від кримінальної відповідальності у зв'язку зі зміною обстановки. Так, у вказаних рішеннях констатується лише перелік даних, що характеризують особу підозрюваного, обвинуваченого, а не зміну обстановки, зокрема, що відповідна особа раніше до кримінальної відповідальності не притягалась, позитивно характеризується за місцем роботи і проживання, щиро розкаялася у вчиненому, повністю відшкодувала завдані збитки, має на утриманні неповнолітню дитину, слабке здоров'я [17; 18]. Отже, слід підтримати думку деяких авторів про те, що інколи досліджувану підставу застосовують $з$ посиланням на так звану недоцільність притягнення винного до кримінальної відповідальності [19, с. 29]. У зв'язку з цим доречно відзначити, що недоцільність притягнення до кримінальної відповідальності як підстава для закриття кримінальної справи була закріплена у ст. 5 КПК України 1927 року [20]. Отже, під час кримінального провадження необхідно встановити та конкретизувати те, яким чином змінилась обстановка, тобто як вчинене діяння втратило суспільну небезпечність або особа перестала бути суспільно небезпечною.

Висновки. 3 огляду на викладене доходимо висновку, що суттєві чинники інституту звільнення від кримінальної відповідальності у зв'язку зі зміною обстановки потребують подальшого комплексного дослідження. Зокрема, це пов'язано з тим, що чітко конкретних дій, які розкривають зміст такої підстави, законодавець не визначає. Крім того, з метою належної реалізації прав та законних інтересів учасників кримінального провадження процесуальний порядок досліджуваної процедури має бути більш детально врегульований в положеннях КПК України. 


\section{Літаратура}

1. Кульчицький В.С., Тищик Б.Й. Історія держави і права України : навч. посібник. Київ : Атіка. 2001. 318 с.

2. Житний 0.0. Звільнення від кримінальної відповідальності у зв'язку зі зміною обстановки. Вісник Національного університету внутрішніх справ. 2004. Вип. 26. С. 23-28.

3. Основы уголовного законодательства СССР и Союзных Республик 1958 года. Ведомости Верхов. Совеma СССР. 1959. № 1. Ст. 6.

4. Кримінальний кодекс України : Закон України від 5 квітня 2001 року № 2341-ІІІ. ВВР України. 2001. № 25-26. Ст. 131.

5. Кримінально-процесуальний кодекс України : Закон України від 28 грудня 1960 року. ВВР Української РСР. 1961. № 2. СТ. 15.

6. Кузнецов А.В. Изменение обстановки как уголовно-правовой способ защиты прав человека: сравнительно-правовой анализ. Вестник Омского университета. Серия «Право». 2011. № 3 (28). С. 176-181.

7. Михайлов К.В. Освобождение от наказания в связи с изменением обстановки. Вестн. ЮУрГУ. Серия «Право». 2007. № 28. Вып. 12. С. 61-68.

8. Губська О.А. Процесуальні питання звільнення особи від кримінальної відповідальності за нереабілітуючими обставинами : автореф. дис. ...канд. юрид. наук : 12.00.09. Київ. 2002. 18 с.

9. Луценко В.Ю. Зміна обстановки як підстава для звільнення від кримінальної відповідальності за злочини проти державної безпеки України. Наше право. 2014. № 7. С. 127-131.

10. Грищенко О. Фікція в законодавчій конструкції звільнення від кримінальної відповідальності у зв'язку зі зміною обстановки. Підприємництво, господарство право. 2019. № 3. С. 268-272.

11. Торбас 0.0. Думка потерпілого щодо можливості звільнення особи від кримінальної відповідальності за кримінальним процесуальним кодексом 2012 року. Юридичний часопис Національної академії внутрішніх справ. 2013. № 2. С. 137-142.

12. Дудоров О.О. Звільнення від кримінальної відповідальності і звільнення від покарання та його відбування:
Протидія злочинності: проблеми практики та науково-методичне забезпечення

порівняльно-правова характеристика. Вісник Національної Прокуратури України. 2010. № 3. С. 46-52.

13. Химичева Г.П., Мичурина О.В., Химичеква О.В. Окончание предварительного расследования прекращением уголовного дела : монография. Рязань : «Узоречье», 2001. $210 \mathrm{c}$.

14. Хряпінський П.В. Заохочувальні норми в кримінальному законодавстві України : монографія. Харків : Харків юридичний, 2009. 448 с.

15. Ярош В.В. Дійове каяття як підстава звільнення від кримінальної відповідальності, передбачена загальною частиною Кримінального кодексу України. Форум права. 2013. № 1. C. 1244-1250. URL: http. //archive.nbuv.gov. ua/e-journals/FP/2013-l/13yvvkku.pdf.

16. Баулін Ю.В. Звільнення від кримінальної відповідальності : монографія. Київ : Атіка. 2004. 296 с.

17. Ухвала Заводського районного суду м. Миколаєва від 18.04.2019 р. Кримінальна справа № 487/959/19. Провадження № 1-кп/487/447/19. Єдиний державний реєстр судових рішень. URL: http://reyestr.court.gov.ua/ Review/81094148.

18. Ухвала Снятинського районного суду Івано-Франківської області від 15.07.2019 р. Кримінальна справа № 351/1248/19. Провадження №1-кп/351/105/19. Єдиний державний реєстр судових рішень. URL: http://reyestr.court.gov.ua/Review/83071548.

19. Степанов В.Г., Шимановский В.В. Прекращение уголовного дела в стадии предварительного расследования : учеб. пособие / отв. ред. А.А. Любавин. Ленинград. 1979. $59 \mathrm{c}$.

20. Уголовно-процессуальный кодекс Украинской ССР. Харьков : Юрид. изд-во Наркомюста УССР, тип. раб.-кооп. Изд-ва «Укр. раб» им. П. Иванова. 1927. 126 с.

Глобенко Г. І., кандидат юридичних наук, доцент, професор кафедри кримінального процесу та організації досудового слідства факультету № 1 Харківського національного університету внутрішніх справ 